\title{
The situation of graduate employees on the Hungarian labor market
}

\author{
Imola Cseh-Papp
}

Ph.D., Habilitated Associate Professor, Head of Institute of Social Sciences and Teacher Training, Hungary

Zoltán Szira

Ph.D., Associate Professor, Institute of Economics, Law and Public Administration, Hungary

\section{Erika Varga}

Ph.D., Associate Professor, Institute of Social Sciences and Teacher Training, Faculty of Economics and Social Sciences, Szent István University, Hungary

\begin{abstract}
Our paper presents the labor market situation of graduate career starter in Hungary based on empirical data (randomly distributed questionnaires of 202 employees). The objective of the research was to survey how this little segment of employees feels on the Hungarian labor market. According to our hypothesis studying and working represent a great value for the graduate career starters and also they are satisfied with their position obtained on the labor market. Despite the uncertain economic situation the results have justified out hypothesis according to which studying represents an outstanding value for graduate career starters and presumes their satisfaction on the llabor market. The examination, which is only part of complex research, was justified by the labor market situation of graduate career starters whose position cannot be described as 'smooth'.
\end{abstract}

Keywords: job satisfaction, graduate career starters, labor market.

JEL Classification: J01, J24.

DOI: $10.21272 /$ bel.1(2).5-11.2017.

(C) The Authors, 2017. This article is published with open access at ARMG Publishing.

\section{Introduction}

The global economic crisis accompanied by labor market equilibrium have made social problems even more serious according to which the difficulties of career starters with higher education degrees to find a job on the labor market have raised more timely issues and can be considered as a cause for concern. As a result of Hungary's higher education that had become widespread after the regime change the number of students soared within a short period while the labor market could only provide them with a more limited range of job offers. The market is saturated and the number of graduate unemployed is growing (Kutas, 2009). That is why career starters must be made more aware of the fact that a degree does not necessarily mean an entry to the world of labor (Cseh-Papp, 2007). From a macroeconomic aspect a problem is that the output of higher education does not meet the requirements of labor market demand either regarding its quality or structure, which can prevent the economy from smooth running and the growth of employment (Elek, 2010).

\section{Literature review}

It is a well-known fact that transition from studies to work has become more varied and complex due to labor market changes and the careers of the young (Teichler, 2004). The first salary can be regarded as a border between adolescence and young adulthood. It can also be regarded as a transitory period in which the young can make attempts and try themselves in different professional fields. At this stage the opportunities and threats of their selected profession can be experienced. The professional impression can have a profound impact on their future jobs can influence their decisions, as well. To sum up, the first labor market experience is decisive (Szabó, 2015).

Several factors may affect the labor market success of the young such as the family background. A Hungarian survey (Szabó, 2015) pointed out that there is a connection between the parents' qualification and the 
future prospect and labor market satisfaction of the would-be employees. The students with neither of the parents having a higher education degree showed the most negative prospect while the children of parents with higher education qualification felt most secure about their future. It is also typical that students of highly qualified parents ae more likely to have a general certificate of secondary education and go on studying, so this way their chances are better on the labor market The unemployed status of the parents, especially that of the father, is frequently passed down to children. In addition to the young with lower qualification the unskilled, those from disadvantaged regions, those with disadvantaged social and economic background, the roma and others living in any other disadvantageous conditions are more exposed to unemployment. The chances of finding a job are higher if internship is spent at a company as practical skills can be acquired under real circumstances. According to the research of Kazainé (2016) it has been proved that university students can mean potential labor force even while studying. During their employment the main criterion is fitting their job to their timetable in a flexible way. However, the young themselves can have an impact on several factors. Chances are higher for a job, person-job fit or professional success if the person selects a job for their interest and skills (Piróg, 2016). This statement calls attention to the importance of career orientation and career consultancy that should be started even from primary school. Good academic achievement, language knowledge and a general certificate of secondary education can result in even higher chances on the labor market. All this has a great influence on further studies, which can mean higher salary and a more stable labor market situation (Quintini, 2014).

The demands and requirements for the quality of labor have been changed, i.e. have become higher and quality job performance, adaptability, ability to learn individually as well as developing competencies are becoming more and more important. In addition to professional knowledge the school should impart essential basic skills for the would-be employees so that they should be able to adapt and develop continuously either at a secondary or higher level of education. Currently, a significant part of the graduates do not have the skills and abilities demanded by the labor market (Makó, 2015).

Labor market satisfaction is dominantly influenced by the fact what job the young employee can find. Selecting the right job needs self-knowledge and conscious job seeking. In the latter case, the would-be employee have to think over their resources, i.e. qualification, skills, knowledge, experience, abilities, personal characteristics and interests together with the expectations from the job and the employer in return and what expectations are necessary to be met. Whether spoken out or not, everyone has certain expectations towards their would-be job, workplace and position. This can hold true for the type of job, work conditions, colleagues, superiors, subordinates and workplace atmosphere and also for salary, spare time and other benefits as well as chances of further studies, promotion, and various tasks at work, creative and renewing spirit and all the expectations that can be regarded important for the job seeker or potential employee. After thinking over the resources and expectations it can be decided which positions and jobs targeted are applied for with higher chances. Considering the above-mentioned facts may be the most difficult in career selection or job seeking. On the other hand, lack of them can result in passion-driven job seeking followed by a lot of disappointment (Budavári-Takács, Csehné, Jekkel, 2015).

\section{Methods}

The examination, which is only a little segment of more complex research, was induced by the not too smooth labor market situation of graduate career starters. The objective was to explore how well-prepared career starter graduates feel on the Hungarian labor market. The sample consisted of 202 randomly selected university graduates who finished their studies 2-3 years ago. The survey covers the entire country but cannot be regarded as representative. According to the hypothesis of the research studying and work are outstanding values for career starter graduates; their career is the result of a consciously planned process so they are satisfied with their labor market situation gained.

\section{Results}

The first part of the questionnaire asked about the demographic features of the respondents. Fifty-five percent of them were women while 5\% men aged between 23 and 28. Regarding schools most of them came from state-owned grammar schools $(66 \%), 20 \%$ from secondary technical school while $13 \%$ attended clerical schools and $1 \%$ to schools run by a foundation. Regarding their mothers $48 \%$ had a degree in higher education. The same holds true for $49 \%$ of the fathers. Forty-two percent of the mothers and $46 \%$ of the fathers possessed a certificate of secondary education. To the slightest extent elementary education appears 
in $10 \%$ of the mothers and $5 \%$ of the fathers, respectively. Thirty-two percent are from towns, $28 \%$ from villages and $22 \%$ live in county seats while $18 \%$ lived in the capital till graduation. The greatest ratio of the examined employees finished their studies in higher education in arts or IT (18-18\%, respectively) followed by engineering (16\%) and economics (14\%). Ten-ten percent studied in health care and health sciences as well as social sciences followed by natural sciences $(6 \%)$, teacher training $(5 \%)$ and the last places are occupied by law and public administration (2\%) and visual arts (1\%).

The questions of the first part were directed at higher education studies. It is essential why the examined employees decided on taking part in higher education. From the calculated results based on frequency it turned out that the greatest role in going on studying was assigned to the easier access to a job on the labor market $(69 \%)$ followed by higher salary with a degree (66\%) and professional interest selected by 635 ad the greatest impact in going on to higher education.

It is a striking result that for $76 \%$ of the respondents in the sample it was professional interest in the major that had the greatest impact on selection. Luckily, for $91 \%$ the fact that the respondents had chances for only this major did not play a role at all. Furthermore, for $85 \%$ of the employers questioned choosing this major accidentally was not typical and also $79 \%$ did not decide on the major because it is easy to finish (Figure 1).

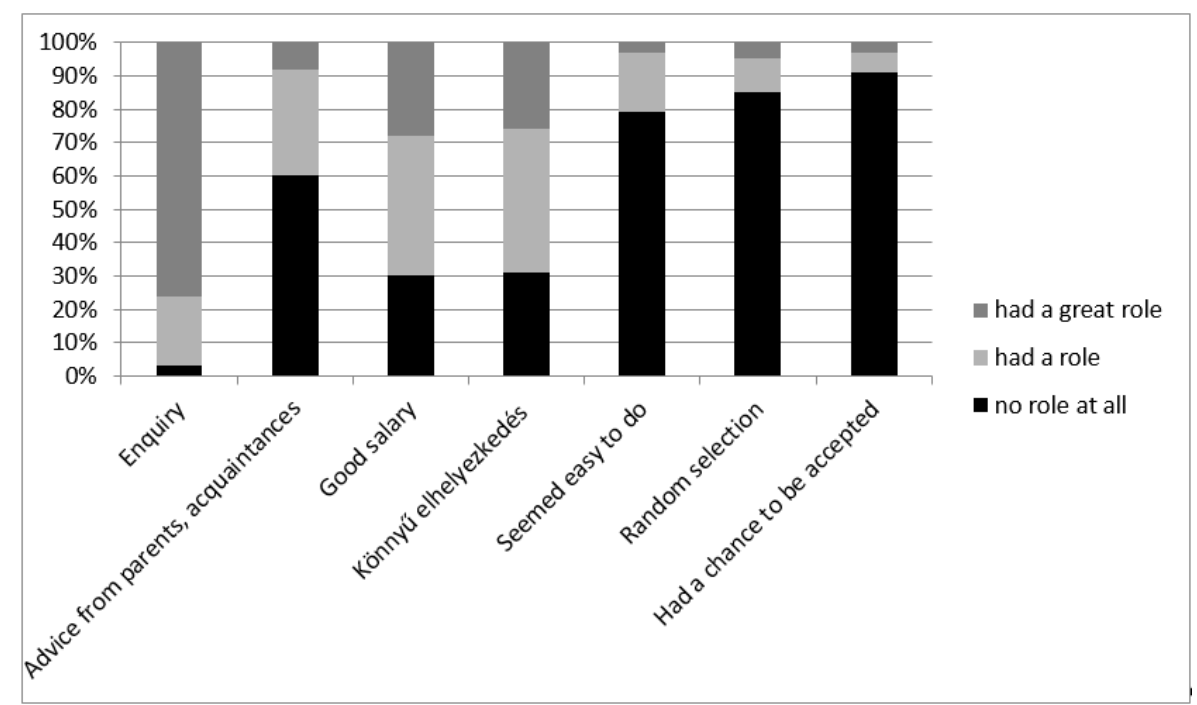

Figure 1. The factors with a role in selecting a job (\%)

$68 \%$ of the graduates decided to go on studying on their own while $20 \%$ asked for the parents' and $7 \%$ their families" opinion. Only $2 \%$ relied on friends or classmates and $1 \%$ on their teachers, respectively.

Sixty-seven percent of the sample indicated two sources of information on which they relied on when deciding on further studies, so they were relatively well-informed. Most of them, i.e. 29\% used the Internet and $26 \%$ the higher education guidelines when selecting the major. Sixteen percent obtained information from acquaintances while $13 \%$ used the university's material. Only $12 \%$ received information from their school/teachers and only $4 \%$ from their parents.

The following part of the examination focused on the labor market situation of the respondents.

Most of the participants (33\%) found a job right after graduation, $31 \%$ had it within 3 months, for $24 \%$ it took half a year and $6 \%$ could start work after a year. However, it is interesting that $6 \%$ finished their studies while having a job already. When examining the characteristics of the current jobs we can see that most of them (one-third of the sample) are still at their first workplace, two-thirds have the second workplace so far.

Of the job preferences of the respondents remuneration takes the first place (98\%) followed by a happy team (95\%) and career development (93\%). At the same time, however, the possibility of working abroad, the company's reputation, flextime and proximity to home as motivating factors were not so decisive (between 62 and 42\%) (Figure 2). 


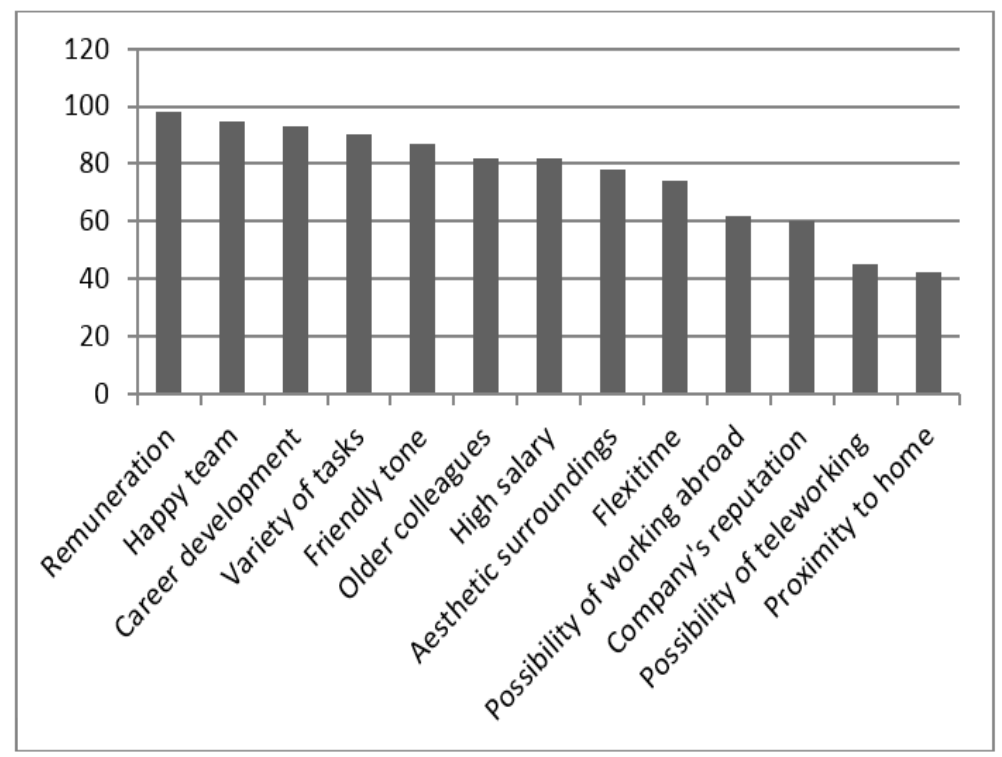

Figure 2. Factors of preference when choosing a job (\%)

The next question analyzed what factors can ensure labor market success on a 7-grade Likert scale (Figure 3). These results reflect the trends that are very timely nowadays, especially personal connections at the first place (6.9) followed by self-assurance (6.7), which exceeds the significance of professional (work) experience (5.8) and qualification (5.8).

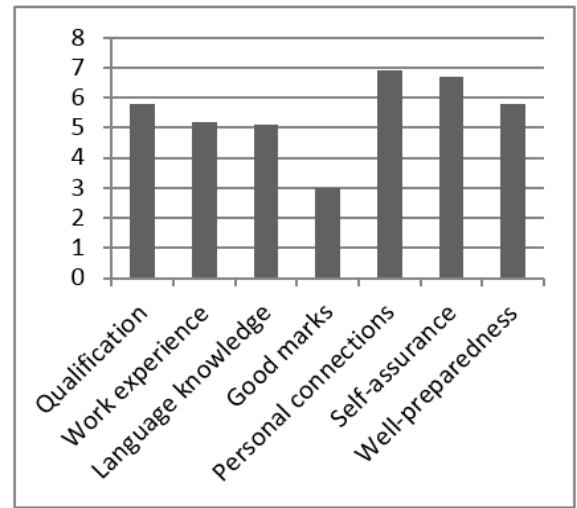

Figure 3. Factors necessary for labor market success (1-7)

Nearly one-third of the respondents (33\%) work for multinational or big companies, a bit fewer (29\%) in the public sector, $17 \%$ for medium-sized enterprises, $13 \%$ small enterprises while $6 \%$ are entrepreneurs. The slightest part of the sample is in the nonprofit sector $(2 \%)$.

Fifty-five percent are subordinates, 29\% middle managers, $16 \%$ senior managers. Fifty-eight percent of the career starter graduates live and work in Budapest, one-fifth in a small town (20\%), $12 \%$ in county seats and $10 \%$ in villages. A bit more than $20 \%$ of the respondents have experienced unemployment while being an entrepreneur, which lasted for 3-6 months.

An important point to examine is how the tasks and responsibilities at work correlate with the qualification of the respondents. In the case of $67 \%$ the current tasks exactly match the qualification; while in $29 \%$ they are most related while according to $4 \%$ they do not match at all.

Examining the attitudes of the respondents on a 7-grade scale we asked them to assess their labor market situation where 1 was the worst and 7 the best grade. The respondents evaluated it to be marketable with an average of 5.26. Between the two genders there were significant differences: 5.56 for men and 4.96 for women, respectively. 
An average of 4.91 was given when evaluating job security. Within it, men think their situation to be slightly more stable than women.

In terms of salary all the respondents were satisfied with an average of 4.57 but men are more satisfied, again. When comparing qualification with the variable of salary, there was a significant correlation. Results have shown that the average of the graduates with IT qualification is 4.93 closely followed by those with technical and business degrees (4.59). Those with a qualification in pedagogy unanimously regard their salary as low t (2.99), which means a category of dissatisfaction.

The issue of favorable prospects of promotion at work was also raised. The respondents gave 4.22 to that point at their own place of work, which can still mean satisfaction although a lower category of it than the previous indicators. Men regard these opportunities more favorable although this difference is not striking.

The examination also surveyed what the respondents expect from the degree and what they receive (Figure 4). Based on the comparison it can be said that there are no huge differences between the values of the expected and received factors. Fewer received a managerial position than they hoped for and the same holds true for social prestige. Chances to work abroad was the last expected and received of all the factors.

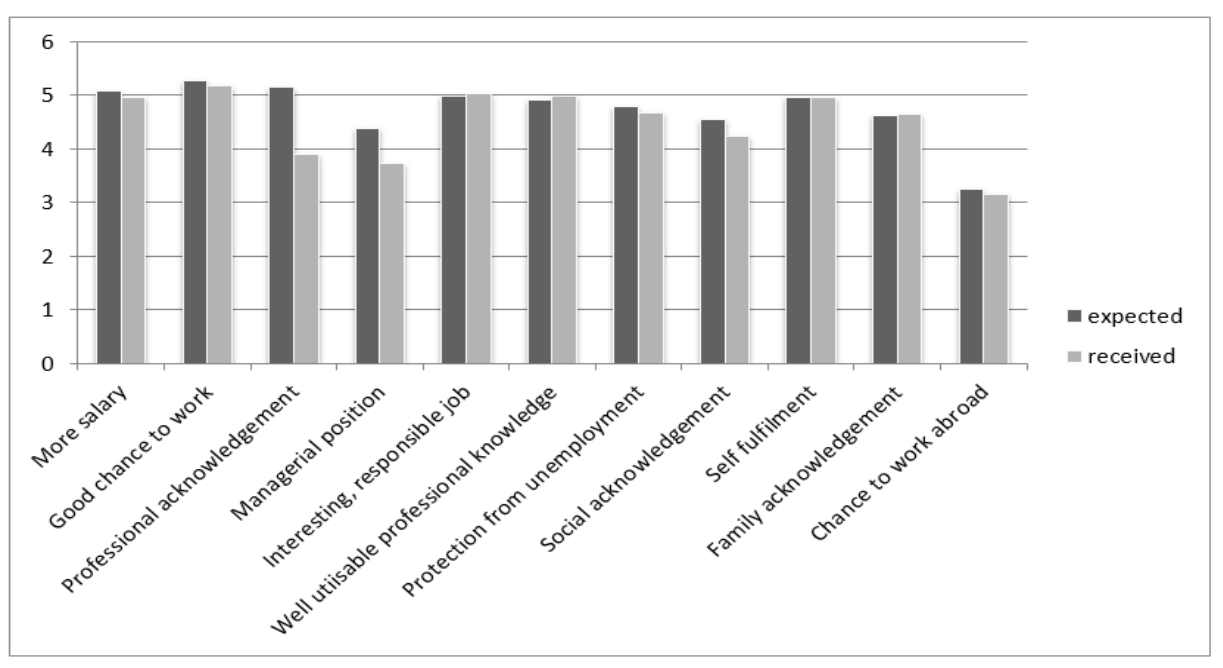

Figure 4. The expected and received factors from a degree (1-7)

One of the central parts of the examination was to find out how graduate career starters feel from certain aspects. Again, they were asked to express their opinion on a 7-degree Likert scale where 1 was the worst, 7 the best value (Figure 5). It can be concluded that altogether the participants feel the best in their relationship (66\%) followed by their workplace (55\%), Hungary (49\%), their family $(46 \%)$ and finally their residential town/city/village (37\%). This latter backlog can be explained by the fact that many of the respondents moved from the parents and did not get accustomed to the new surroundings yet. Their partnership was given most of the maximum scores and there was none of the worst grades in this category.

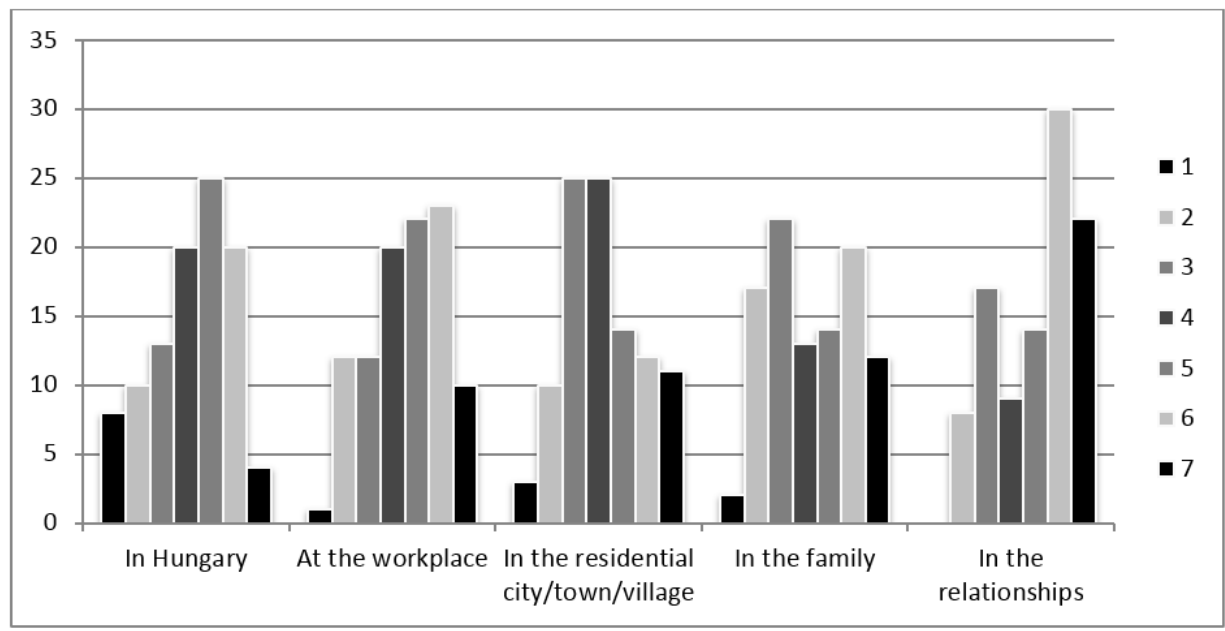

Figure 5. The well-being of the respondents from 1 to 7 'How are you feeling? (\%) 
The thoughts on the future plans of the respondents are analyzed by the next question on the basis of a 7 grade Likert scale. The highest value was assigned to the „I know what I am able to do" answer with 5.8 but all of them convey self-assurance and decisiveness (Figure 6).

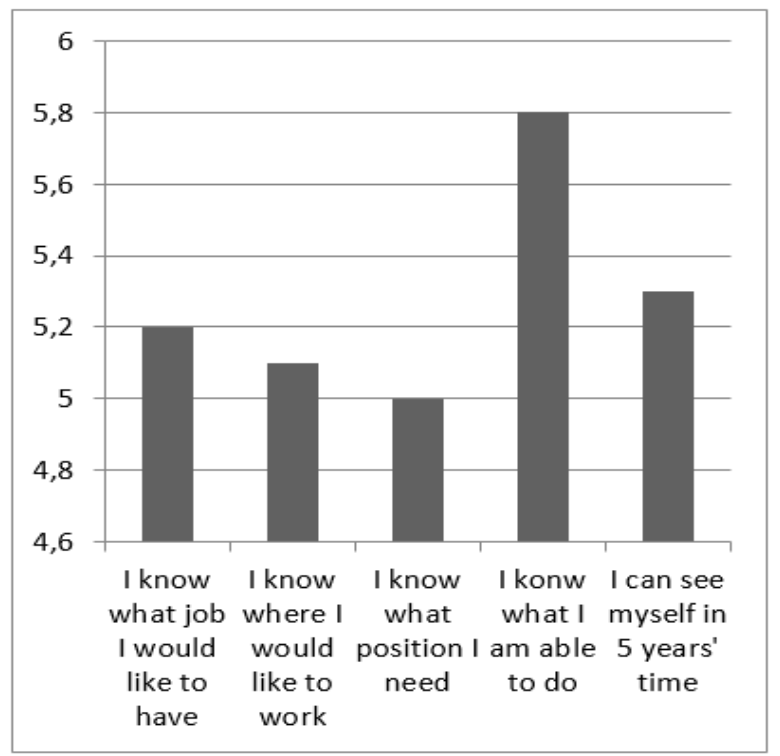

Figure 6. The future plans of the respondents (1-7)

Finally, the participants were asked how they see themselves in 10 years' time. Nearly all of them mentioned "successful career", "acknowledgement" and "professional improvement" (67\%), as an objective. This is closely followed by a "happy family" (56\%), "raising children" (48\%) and "financial security" (47\%). For many of them it is essential that they should have enough free time for their families and themselves. There were some respondents (only 12\%) who regarded further training as an important prerequisite of professional success.

\section{Conclusions and discussion}

The first part of the hypotheses for the research according to which studying represents a strikingly high value for the graduate career starters was justified as many of them had some family background regarding both the qualification of the parents or their secondary school studies. The passion for their selected profession is what has guided them to higher education and selected their jobs on their own. Work as a value also plays a significant part in their lives. It turns out of the fact that many respondents thought a degree in higher education would make it easier for them to find a job and hoped that their qualification could provide them with labor market stability and security. On the other hand, their majors were selected after close investigation.

The second part of the research that supposed the labor market satisfaction of the graduate ob. seekers was also proved. Almost all of the respondents had a job which is connected to their original qualification; they regarded their degree marketable, appreciated their current job security, and were satisfied with their salary and prospects for promotion. An interesting difference was that men were more satisfied with their labor market situation than women. What was expected from the degree at the beginning of their studies in higher education was obtained (except the excessive expectations toward being a manager). It is good news that they feel good at their workplaces and in the country and professional development is more frequently on their agenda, which also proves their commitment.

\section{Recommendations}

From the comparison of the expected and received factors from higher education as well as the attitude examination it turned out that the graduates did not have sufficient and real information on the world of labor when finishing their studies. Knowledgeability partly depends on the educational system and partly on the students. A solution to the problem could be if more experts could be invited to the events or conferences of the institutions or faculties even as a guest speaker by the higher education institutions so that students could have direct access to information from experts with several decades of experience. Furthermore, it is also essential that students should visit career offices, job centers and career days where career starters are assisted by different leaflets and work agencies. 


\section{References}

1. Elek, L. (2010). Munkaerőpiac és felsőoktatás: a legbiztosabb a ma még nem is létezö szakma! Humánpolitikai Szemle, 6, 40-44.

2. Kutas, J. (2009). Gondolatok a képzés és foglalkoztatás összehangolásának céljairól és módszereiről. Munkaügyi Szemle, 2, 76-82.

3. Teichler, U. (2004). Changes in the Relationships between Higher Education and the World of Work on the Way towards the European Higher Education Area. EUA Conference „University and Society: Engaging Stakeholders", Marseille, 1 - 3 April 2004.

4. Csehné, Papp I. (2007). Az oktatás és a munkaerőpiac állapota közötti kapcsolat Magyarországon, Gazdálkodás, 1, pp. 60-66.

5. Budavári-Takács, I., Csehné Papp, I., Jekkel, O. (2015). Karrier építési tudatosság vizsgálata fiatal felnőttek körében, in: Innováció - növekedés - fenntarthatóság, Budapesti Kereskedelmi és Iparkamara, Budapest, szerk. Csehné Papp I., Budavári-Takács, I., Mészáros, A., Iliás, A., Poór, J., pp. 44-49.

6. Kazainé Ónodi A. (2016). Munkavállalói preferenciák az egyetemi hallgatók körében. Mühelytanulmány, Budapesti Corvinus Egyetem, Vállalatgazdaságtan Intézet. p. 25.

7. Makó, Á. (2015). A szakképzett pályakezdők munkaerő-piaci helyzete és elhelyezkedési esélyei. Közgazdasági Szemle, 5, 502-524.

8. Piróg, D. (2016). The impact of degree programme educational capital on the transition of graduates to the llabor market. Studies in Higher Education, 41(1), 95-109.

9. Quintini, G. (2014). Skills at Work: How Skills and their Use Matter in the Labor Market. http://www.oecd-ilibrary.org/docserver/download/5jz44fdfjm7j.pdf?expires=1477848494\&id=id\&accname= guest\&checksum=E1D1B6084A2932C984FA4D7F2A9B1705 (Accessed Octóber 30, 2016).

10. Szabó, A. (2015). A magyar egyetemisták és föiskolások Magyarországon. Belvedere Meridionale, Szeged, p. 43. 